\title{
ON THE NATURE OF INTERPRETATION IN INTERNATIONAL LAW
}

\author{
Katayoun Hosseinnejad*
}

\begin{abstract}
This paper sets out a theoretical approach to the nature of interpretation that is intended to overcome some of the challenges of treaty interpretation in international law. By adhering to the approaches of Gadamer and Wittgenstein, it is argued that interpretation is a reciprocal dialogue between the reader and text with the mediation of the 'tradition' and 'language-games'. Although it seems there exists no agreement among legal theorists on the nature of interpretation, reviewing their approaches reveals that they have acknowledged the dependency of meaning upon the traditions and practices of communities. This finding paves the way for providing a new reading for the system of interpretation provided by articles 31 and 32 of the Vienna Convention on the Law of Treaties (VCLT). It is argued that although the VCLT integrates some of the elements of current interpretive methods, ultimately the VCLT adopts its own unique approach. The nature of international law requires taking into account the 'conventionalist theory' to determine meaning based on the acts of the law's subjects. Nevertheless, the nature of interpretation requires that the terms be understood with the mediation of the 'language-games' which is realised by the inclusion of 'the relevant rules of international law'.
\end{abstract}

\section{A. INTRODUCTION}

The centrality of interpretation to the law in general lies in two of law's inherent features. On one hand, law, as 'the projection of an imagined future upon reality', ${ }^{1}$ needs to predict the future. This legal prediction, however, suffers from two main human failings - in HLA Hart's words, these are human beings' relative ignorance of facts and their relative indeterminacy of aim. ${ }^{2}$ On the other hand, in its search for justice, the law tries to balance the concepts of the 'self' and the 'other', and therefore, as Michel Rosenfeld describes, avoids speaking in the voice of either one of them; rather, the law embraces a universal language that transcends the individualities of all the selves that come within its sweep. ${ }^{3}$ The gap between 'singular and universal' or 'abstract and concrete', however, cannot be surmounted without violence: every insistence on the self-claim is bound to do violence to the other, and every restraint in pursuing the self-claim does violence to itself. That is why legal interpretation, according to Robert Cover 'takes place in a field of pain and death'. ${ }^{4}$

\footnotetext{
* PhD Candidate in International Law, Graduate Institute of International and Development Studies. Email: katayoun.hossein@graduateinstitute.ch.

${ }^{1}$ Robert Cover, 'Violence and the Word' (1986) 95 Yale LJ 1601, 1604.

${ }^{2}$ HLA Hart, The Concept of Law (OUP 1994) 128.

${ }^{3}$ Michel Rosenfeld, Just Interpretations: Law Between Ethics and Politics (University of California Press 1998) 56.

${ }^{4}$ Cover (n 1) 1601.
} 
In international law, the articulation of the rules of interpretation in the VCLT has not reduced the complexity of legal interpretation. Rather, it has mainly shifted the focus of scholars from the 'nature' of interpretation, which requires theoretical treatment, to the 'how' of the interpretation. However, this scholarly shift in focus largely neglects the fact that, in the absence of a theoretical approach to interpretation in international law, articles 31 and 32 of the VCLT are downgraded to describing some techniques of interpretation which at best can serve as rhetorical tools. A brief review of the adjudication practices under the VCLT reveals just how far the practice of interpretation stands from the underlying objectives of the VCLT's rules of interpretation: certainty and non-arbitrariness. ${ }^{5}$

This paper seeks to provide a theoretical approach to the nature of interpretation by resorting to philosophical and linguistic insights on interpretation and meaning, with the aim of overcoming some of the challenges of treaty interpretation in international law. However, this paper is by no means a comprehensive treatment of interpretation; it is only the first step in determining the foundational elements thereof. Therefore, issues such as practical methods of interpretation, inter-temporal law, and evolutive interpretation fall outside the direct scope of this paper.

Section B takes the theories of Gadamer and Wittgenstein as starting points for shedding light on the nature of interpretation. This section starts with a brief review of the evolution of the concept of interpretation, from its beginnings in techniques used to extract meaning from texts, to a philosophical subject that, by questioning the existence of objective knowledge, focuses on the interplays between the text, the author, and the reader. Based on the philosophical approaches of Gadamer and Wittgenstein, this section suggests that interpretation cannot be reduced to bare text or to the original intentions of authors. Rather, interpretation is a reciprocal dialogue between the reader and text, mediated by the traditions and practices of particular communities.

Section $\mathrm{C}$ studies the approaches of legal theorists to interpretation, with the aim of showing that such a philosophical linguistic insight can be tracked in their theories. The change in the philosophical paradigm of knowledge and being bears on legal theories and the

\footnotetext{
${ }^{5}$ The main objective of codification of these rules, as articulated by Roberto Ago, the chairman of the International Law Commission in 1946, was to ensure the certainty of law, which depended mainly on the certainty of the rules of interpretation. ILC, 'Summary record of the 726th meeting' UN Doc A/CN.4/SR.726, para 34. Likewise, Sir Humphrey Waldock, the last Special Rapporteur of the Commission, dismissed the doctrinal resistance toward codification of any rule on interpretation, by declaring that the interpretation of treaties without arbitrariness; and in accordance with the principles of law is the necessary implication of the pacta sunt servanda principle. ILC, 'Third Report on the law of treaties, by Sir Humphrey Waldock, Special Rapporteur' (Waldock Third Report) UN Doc A/CN.4/167 and Add.1-3, 54 para 8.
} 
conception of law in general. As a result, either the traditional theories have evolved in a way to encompass such insights, or new theories and approaches have emerged. The inclusion of the 'internal point of view' as an integral element of the concept of law in the theories of major legal positivists such as HLA Hart, Joseph Raz and Hans Kelsen, is an acknowledgment of the claim by hermeneutic theorists that 'it is inherently paradoxical to study human beings, who have a particular subjective point of view, from a detached and external perspective'. ${ }^{6}$ For example, in determining what is the norm, Kelsen maintains that in order for the act of will to have objective meaning, the 'ought' should be considered as an 'ought', 'not only from the point of view of the individual who has performed the act, but from the point of view of the individual at whose behavior the act is directed, and of a third individual not involved in the relation between the two'. ${ }^{7}$

Subsequently, legal interpretation, as an important subject within the conceptualisation of law, was transformed from a mere technical tool into a concept that could itself serve as the basis for a legal theory. There are still, however, international law scholars who follow the Classics and advocate using certain techniques of interpretation without seeing any need to lay down any foundation for the concept of interpretation. Although their works are very influential and important, they fall outside the scope of this paper. ${ }^{8}$ This is also true of the work of Emer de Vattel and Hugo Grotius, as they clearly belong to the traditional way of thinking about interpretation.

This study will be done by using the methodology offered for studying 'contested concepts', as there seems to be no agreement among scholars on the nature of interpretation. ${ }^{9}$ Understanding 'interpretation' as a contested concept suggests a theoretical research method that goes beyond appeal to empirical evidences, linguistic usage, or the canons of logic alone, because each definition of the contested concept is based upon divergent patterns of thought. Therefore, different theoretical opinions on the subject will be examined with the aim to

\footnotetext{
${ }^{6}$ Hans H Kögler and Karsten R Stueber, Empathy And Agency: The Problem Of Understanding In The Human Sciences (Westview Press 1999) 4.

${ }^{7}$ Hans Kelsen, Pure Theory of Law (The Lawbook Exchange, 1967) 7.

${ }^{8}$ For example see Richard K Gardiner, Treaty Interpretation (OUP 2010); Alexander Orakhelashvili, The Interpretation of Acts and Rules in Public International Law (OUP 2008); and Ulf Linderfalk, On the Interpretation of Treaties (Springer 2007).

${ }^{9}$ For some scholars, interpretation has a broad sense and includes any kind of 'explanation', or 'understanding'. Other scholars, however, believe that there is a way of understanding a text, which is not interpretation. Some believe that interpretation ends at the point at which language ends, and thus giving a meaning to a text beyond its semantics is not an act of interpretation. Others think that interpretation starts when semantics end. Some advocate the view that interpretation is an effort to determine the meaning according to the intention of authors of the text. Others adhere to the view that meaning can only be found in the usage, the custom, or the interpretive community.
} 
demonstrate the relations between the rival uses of such a concept in different legal thoughts, since these disagreements are not 'haphazard or random, but will tend to be mutually supportive or interlocking, ${ }^{10}$

Section D provides a new reading of articles 31 and 32 of the VCLT based upon the conception of interpretation as the reciprocal interaction between the text and the reader, with the mediation of tradition and practice. It will be argued that while the system of interpretation provided by VCLT recognises the value of the text, intention, and purpose of law in the process of interpretation, the VCLT provides its own approach to interpretation.

\section{B. PHILOSOPHICAL APPROACHES TO INTERPRETATION}

In its early days, interpretation was conceived of only as a collection of specialised techniques for revealing the original meaning of literary and religious texts. ${ }^{11}$ For example, Greek and Roman rhetoricians developed a system of argumentation of which one branch was concerned with the proper interpretation of legal texts. ${ }^{12}$ For them, the word 'canon' meant a technical rule of grammar under which a word's meaning or usage could be ascertained. ${ }^{13}$ These traditional methods of interpretation relied on Aristotelian analysis, according to which a text was thought to present a series of reasoned positions that were available for analysis by anyone trained in logical operations. Most importantly, the text was thought to contain a unitary meaning that corresponded to the author's intention. ${ }^{14}$ As a result of this thinking, the Classical scholars would propose a list of maxims for interpretation, without seeing any need to lay down a theory about the concept of interpretation. It is in this tradition that the work of Grotius and Vattel on interpretation should be understood. Grotius, for instance, presents a great number of maxims, including the best interpretation of sentences such as 'Carthage shall be free'. ${ }^{15}$ Much the same is true of Vattel's work, which supplies a long list of maxims founded on 'reason and authorized by the law of nature', to be applied in accordance with the circumstances. ${ }^{16}$

\footnotetext{
${ }^{10}$ This methodology is based on what was proposed by Gray in studying the 'essentially contested concepts': John N Gray, 'On the Contestability of Social and Political Concepts' (1977) 5 Political Theory 331. In particular 344. ${ }^{11}$ Hans-Georg Gadamer, Joel Weinsheimer and Donald G Marshall, Truth and Method (Continuum 2004) 175.

${ }^{12}$ David J Bederman, Classical Canons: Rhetoric, Classicism and Treaty Interpretation (Dartmouth Publishing Co 2001) 11 .

13 ibid 18.

${ }^{14}$ Mark Poster, 'Interpreting Texts: Some New Directions' (1985) 58 Southern California Law Review 15, 15.

${ }^{15}$ Jan Klabbers, 'Virtuous Interpretation' in Malgosia Fitzmaurice, Olufemi Elias and Panos Merkouris (eds), Treaty Interpretation and the Vienna Convention on the Law of Treaties: 30 Years on (Brill 2010) 27, Also Bederman (n 12) 119.

${ }^{16}$ Emer de Vattel, The Law of Nations, vol 2 (Liberty Fund 2008) para 262.
} 
It was not until the nineteenth century that 'understanding' was considered as a general problem requiring philosophical treatment. Friedrich Schleiermacher, whose work forms part of the foundation of modern hermeneutics, changed the paradigm of interpretation by recognising that 'the possibility of misunderstanding is universal'. ${ }^{17}$ For Schleiermacher, interpretation and understanding were closely interwoven, like the outer and the inner word, and therefore, every problem of interpretation was, in fact, a problem of understanding. Thus, it is no surprise that he defines hermeneutics as 'the art of avoiding misunderstandings' ${ }^{18}$ Schleiermacher's theory of interpretation, which can be summarised in his famous formula 'to understand a writer better than he understood himself', was meant to achieve understanding by the 'reconstruction of the production' which 'inevitably renders many things conscious of which the writer may be unconscious'. ${ }^{19}$

The interplay between a text, its meaning, and the reader reaches its momentum by the ontological-linguistic turn taken by Martin Heidegger, and Gadamer who asserts that 'being that can be understood is language' ${ }^{20}$ Language as the medium in which understanding and agreement concerning an object occur, however, is not the focus of hermeneutics. The focus, according to Gadamer, is on the reciprocal relationship between the text and the reader. ${ }^{21}$ Gadamer rejects dividing the hermeneutic problem between the subjectivity of the interpreter and the objectivity of the meaning. Rather, he asserts that interpreters will approach a text with certain 'pre-understandings' about the text, which Gadamer calls 'prejudices'. Prejudice which does not necessarily mean false judgment - is a condition for all understanding. ${ }^{22}$ Gadamer defines 'prejudice' as a 'judgment that is rendered before all the elements that determine a situation have been finally examined'. ${ }^{23}$ These judgments are conditioned by history and tradition, thus it is the tradition that 'determines in advance both what seems to us worth inquiring about and what will appear as an object of investigation' ${ }^{24}$ Admitting that such prejudices give a specific 'horizon', a 'range of vision that includes everything that can be seen from a particular vantage point', ${ }^{25}$ Gadamer calls for the 'historically effected consciousness' to be aware that interpretation requires the 'fusion of horizons' between the text and the reader,

\footnotetext{
${ }^{17}$ Gadamer, Weinsheimer and Marshall (n 11) 179.

18 ibid 184-185.

19 ibid 191.

20 ibid 470.

21 ibid 370.

22 ibid 278.

23 ibid 273.

24 ibid 300.

25 ibid 301.
} 
through which the 'old and new are always combining into something of living value'. ${ }^{26}$ To bring about this fusion in a regulated way is only possible through application. That is why, according to Gadamer, application is an essential element of interpretation and the only tool with which to bridge the gap 'between then and now, between the Thou and the I': ${ }^{27}$

All reading involves application, so that a person reading a text is himself part of the meaning he apprehends. He belongs to the text that he is reading. The line of meaning that the text manifests to him as he reads it always and necessarily breaks off in an open indeterminacy. He can, indeed he must, accept the fact that future generations will understand differently what he has read in the text. ${ }^{28}$

A similar approach to the nature of interpretation and meaning, but through a linguistic lens, can be found in the philosophical theory of Ludwig Wittgenstein. ${ }^{29}$ Before outlining his theory, it is worth noting that in linguistic theories, a distinction is drawn between theories on semantic description of languages and theories which seek to determine the foundation of linguistic meaning. Theories of the first kind, which are called 'semantics', belong to logic and linguistics and are designed for studying the meaning of expression by elements of a language. In contrast, theories of the second kind are 'foundational' and aim to answer the most basic questions concerning linguistic meaning - questions about its very nature. ${ }^{30}$ That said, although these two types of theories are distinct, they are closely connected. That is why Donald Davidson, in approaching the question of 'what is it for words to mean what they do?', suggests asking two different questions: 1) what form should semantics take, and 2) what is it that makes a semantic theory correct for a particular language, ie what determines meaning? ? $^{31}$

Foundational theories of meaning are developed by the acknowledgment that the meanings of words cannot be derived from their physical properties or reduced to the realworld objects to which they refer. Among different theories, ${ }^{32}$ Wittgenstein suggests that the

\footnotetext{
26 ibid 209.

27 ibid 329.

28 ibid 335.

${ }^{29}$ Gadamer himself acknowledges this similarity and notes: 'I am really in complete agreement with the late Wittgenstein, and I call that hermeneutics!' in Hans-Georg Gadamer and Rod Cotlman, A Century of Philosophy: Hans Georg Gadamer in Conversation with Riccardo Dottori (Bloomsbury Academic 2006) 74. For the detailed discussion on the asymmetry between the work of Gadamer and Wittgenstein see: Desiree Weber, 'Interpreting Interpretation: Gadamer's Hermeneutic Theory in Language and Politics' (2007) Honors Projects <http://digitalcommons.macalester.edu/poli_honors/10> accessed 24 September 2015.

${ }^{30}$ Kathrin Glüer-Pagin, 'Theories of Meaning and Truth Conditions' in M García-Carpintero and M Kölbel (eds)

The Continuum Companion to the Philosophy of Language (Continuum 2012) 84.

${ }^{31}$ Donald Davidson, Inquiries into Truth and Interpretation (Clarendon Press 1984) xiii.

32 There are six main approaches to the foundational theories of meaning: a) Mentalist and intentionalist theories, as associated with Paul Grice, claims that the meanings of sentences are determined by the contents of the communicative intentions of users of those sentences. b) Interpretational theory, proposed by Davidson, asserts that meaning is determined by the 'principle of charity' on the basis of non-semantic facts about sentences held
} 
meaning of an expression is determined by its use. In Philosophical Investigation, Wittgenstein argues that the meaning of any given linguistic expression is determined by the 'languagegames' in the community in which the expression is used. ${ }^{33} \mathrm{He}$ asserts that language is not something fixed, 'but new types of language, new language-game[s] ... come into existence and others become obsolete and get forgotten'. The use of the word 'language-game' by Wittgenstein is meant to emphasise the reciprocal relationship that leads to meaning such that speaking of language can be described as 'a form of life'. ${ }^{34}$ Wittgenstein's understanding of the mediation of language-games in meaning is remarkably close to Gadamer's understanding of the role of tradition. Both scholars speak of the relative stability of language and reject transcendental truth as the foundation of language. Similarly, language-games and the fusion of horizons explain how meaning is adjusted when two (or more) speakers are in dialogue. ${ }^{35}$

The philosophical-linguistic approaches discussed above suggest that we do not discover meaning by limiting our vision to bare text, or to the original intentions of authors. Rather, the tradition and practices within a specific community determine the meanings of terms used in that community. It may be argued, however, that such a philosophical-linguistic insight on the dependency of meaning upon social practices and tradition cannot be applied to law, which is aimed at providing its subject with certainty and stability. For this reason, we must also consider the approaches of different legal theorists to the nature of interpretation.

\section{APPROACHES OF LEGAL THEORISTS TO THE NATURE OF INTERPRETATION}

Rejecting the intentionalist theory of meaning, Kelsen warns against believing the fiction that a legal norm admits of only one meaning as the 'correct' interpretation, because such a view falsely presents a purely political value judgment as scientific truth. ${ }^{36}$ For Kelsen, interpretation is 'an intellectual activity, which accompanies the process of law application in its advance

\footnotetext{
true under observable circumstances by ideal interpreter. c) Casual theories as developed by Saul Kripke, suggest that the meaning of an expression is fixed neither by the thoughts of agents nor by what an ideal interpreter would say, but rather by the causes of utterances; d) Reference magnetism theory emphasises the relatively natural entities which serve as 'magnets' for expressions to refer to; e) Internalist theory, as developed by Noam Chomsky, suggests that linguistic expressions are related to inner states of speaker and hearers and communication depends on a similarity of these states.

${ }^{33}$ Ludwig Wittgenstein and GEM Anscombe, Philosophical Investigations: The English Text of the Third Edition (Prentice Hall 1958) para 7.

34 ibid para 23.

${ }^{35}$ Gadamer in his preface to the second edition of his book Truth and Methods writes: 'Wittgenstein's concept of 'language-games' seemed quite natural to me when I came across it.' Gadamer, Weinsheimer and Marshall (n 11) xxxvi footnote 13. See alsoWeber (n 29) 19.

${ }^{36}$ Kelsen (n 7) 356.
} 
from a higher to a lower level' ${ }^{37}$ In other words, interpretation is linked with the hierarchical structure of legal orders. ${ }^{38}$ The result of a legal interpretation, according to Kelsen, can only be the ascertainment of the frame which the law that is to be interpreted represents, and consequently, the cognition of several possibilities within the frame. ${ }^{39}$ Kelsen rejects the possibility of a method that would reach only one correct answer or that would favor one interpretation over the other. To choose the 'right' interpretation, among other possibilities, 'is not a question of cognition directed toward positive law... but of legal politics' ${ }^{40}$

Hart, as well, does not propose a theory of interpretation, although terms' meanings play an important role in his theory. Hart's approach to adjudication and the meanings of rules was inspired by the skepticism of the Realism movement of the $1930 \mathrm{~s} .{ }^{41}$ Hart asserts that to be able to regulate behavior, a rule 'must have some standard instance in which no doubts are felt about its application'. ${ }^{42}$ At the same time, a penumbra of debatable cases will exist in which words are neither obviously applicable nor obviously inapplicable. As a result of this approach, in Hart's theory, there is a 'core of certainty' and 'penumbra of doubt', which conveys upon all rules a 'fringe of vagueness' or 'open texture'. ${ }^{43}$ As such, the uncertainty which exists in all legal rules cannot be solved by logical deduction, ${ }^{44}$ or 'mechanical deduction from rules with predetermined meaning'. ${ }^{45}$ Hart therefore warns that judges as interpreters always make choices in penumbral cases, even if the judge as interpreter 'either does not see or pretends not to see that the general terms of this rule are susceptible of different interpretations and that he has a choice left open uncontrolled by linguistic conventions' ${ }^{46}$ Interpretation in these cases, according to Hart, should be done in the light of social aims, ${ }^{47}$ while respecting the judicial virtues: impartiality and neutrality in surveying the alternatives, consideration for the interests of all who will be affected by the judge's decision, and a concern to deploy some acceptable general principle as a reasoned basis for decision. ${ }^{48}$

Despite the distinction Hart makes between the 'core' meaning and the 'penumbra', he does not assume the existence of a transcendental or inherent meaning even in plain cases, as

\footnotetext{
37 ibid 348.

${ }^{38}$ Jörg Kammerhofer, Uncertainty in International Law: A Kelsenian Perspective (Routledge 2012) 105.

${ }^{39}$ Kelsen (n 7) 351.

40 ibid 352-353.

${ }^{41}$ HLA Hart, 'Positivism and the Separation of Law and Morals' (1958) 71 Harvard Law Review 593.

42 ibid 607.

${ }^{43}$ Hart, The Concept of Law (n 2) 123.

${ }^{44}$ Hart, 'Positivism and the Separation of Law and Morals' (n 41) 607.

${ }^{45}$ Hart, The Concept of Law (n 2) 204.

${ }^{46}$ Hart, 'Positivism and the Separation of Law and Morals' (n 41) 610.

47 ibid 611.

${ }^{48}$ Hart, The Concept of Law (n 2) 204.
} 
he says that the plain cases, "where the general terms seem to need no interpretation and where the recognition of instances seems unproblematic or "automatic", are considered as plain because 'there is general agreement in judgments as to the applicability of the classifying terms'. ${ }^{49}$ This indicates why Hart believes that the 'application of law in concrete cases requires interpretation', ${ }^{50}$ without distinguishing between hard and plain cases. In other words, it is the practices in a specific community that render the applicability of a rule unproblematic or automatic. Therefore, it can be concluded that meaning in Hart's theory is not determined merely by reference to its semantics, but by 'traditions' in the community.

Like other positivists, Raz rejects the possibility or necessity of giving any general theory of interpretation. However, he does discuss in detail what he understands the concept of interpretation to be. In doing so, Raz implicitly rejects the intentional theory by asserting that 'meaning is a public and social phenomenon'. ${ }^{51}$ He bases the foundation of meaning on 'the dependence of language and other carriers of meaning on conventions' and asserts that the existence of such conventions of meaning 'in a certain population indicates that they all regard the same things as having the same meaning'. ${ }^{52}$ The 'authoritative intention thesis' is crucial, according to Raz, only for the legitimation of legislation, but it has no use as an aid to or method of interpretation. Put another way, 'intention legitimates, but conventions interpret'. ${ }^{53}$

Although he has not laid down a general theory of interpretation, Raz views interpretation as comprising 'both the activity of explaining or displaying the meaning, and its product' ${ }^{54} \mathrm{He}$ attributes four focal features to interpretation in general, ${ }^{55}$ and three additional features which are specific to interpretation in law. Among these features, Raz particularly rejects the view that interpretation is limited to semantics, by stressing that a 'good interpretation provides understating, not merely knowledge' and that this element 'in itself excludes the giving of a dictionary meaning, substitution of synonyms or near synonyms and translation'. ${ }^{56}$ Nevertheless, Raz holds that there are 'no useful universal recipes for

\footnotetext{
49 ibid 126.

50 ibid 204.

${ }^{51}$ Raz claims that the focus should be on why we interpret and not on how to interpret. His reason for such a rejection has two aspects: on the moral end, no general theory of interpretation is possible because there is no moral theory capable of stating in specific terms 'what is to be done in all the situation possible in a particular society'. On the side of establishing the content of law, a general theory is unnecessary mainly because 'lawmakers know the ways in which their law is interpreted'. Joseph Raz, Between Authority and Interpretation (OUP 2009) 119-121.

52 ibid 229.

53 ibid 288-289.

54 ibid 299.

55 The four features are: interpretation is of an original; interpretation states or shows the meaning of an original; interpretation is subject to assessment as right or wrong; and interpretation is an intentional act. ibid 268.

56 ibid 301.
} 
interpretation' because interpretations are guided by practice-based norms and constrained by the meaning of objects, both of which are subject to change over time. Thus, the only general guide is in understating what interpretation is for. ${ }^{57}$

Lon Fuller asserts that the problem of interpretation occupies 'a sensitive, central position in the internal morality of law'. ${ }^{58}$ The reason that such centrality has not been recognised in all legal theories is because 'law is regarded as a one-way projection of authority instead of being conceived as a collaborative enterprise'. ${ }^{59}$ Fuller maintains that meaning is derived from culture, such that when a legislator uses language, 'he intends that language to have the meaning it has in his culture; he is himself a participant in that culture and he means by his words not what the dictionary says they mean, but what his fellow citizens would mean when they use them'. ${ }^{60}$

For Fuller, language represents the 'interactional phenomenon par excellence; its forms arise out of and live by interactions', therefore, communication by words cannot be seen as a matter of 'shipping packages of meaning from one head to another'. ${ }^{61}$ The meaning of a word cannot be resolved by recourse to the intentions of authors, but should be arrived at by the interpreter at the time of application of the words to a concrete context, because with 'the passage of time' some conception of 'what is fit and proper' will influence the text. And what is fit and proper in the concrete specific context of an interpreter's local culture is 'implicit in the practices and attitudes of the society of which he is a member' ${ }^{62}$

In his famous debate with Hart, Fuller attacks Hart's core meaning theory by giving the example of punishing a man who falls asleep while waiting for a delayed train, in accordance with a rule providing that a man sleeping in a railway station is punishable; and with this argument that his sleep represents the 'obvious instance' contemplated by that law. ${ }^{63} \mathrm{He}$ criticises Hart's theory of interpretation as a 'pointer theory of meaning' which focuses on the individual things, or distinct situations of facts, rather than toward general ideas or the significance of those facts in human affairs. ${ }^{64}$ In considering legal text, meaning is assigned not to a single word but to a sentence, a paragraph or a whole page or more of text; a paragraph surely does not have a 'standard instance' that remains 'constant whatever the context in which

\footnotetext{
57 ibid 321-322.

${ }^{58}$ Lon L Fuller, The Morality of Law (Yale University Press 1969) 91.

59 ibid 227.

${ }^{60}$ Lon L Fuller, Anatomy of the Law (Greenwood Press 1976) 58.

${ }^{61}$ Fuller, The Morality of Law (n 58) 227.

${ }^{62}$ Fuller, Anatomy of the Law (n 60) 59.

${ }^{63}$ Lon L Fuller, 'Positivism and Fidelity to Law: A Reply to Professor Hart' (1958) 71 Harvard Law Review 630, 664.

${ }^{64}$ Fuller, The Morality of Law (n 58) 84.
} 
it appears'. ${ }^{65}$ Fuller maintains that Hart's approach to interpretation is limiting the judicial process to what he labels as 'cataloguing procedure', which is contrary to the larger responsibilities that judges have to 'treat' a case. ${ }^{66}$ It becomes apparent that Fuller's theory of interpretation is very close to the reciprocal interplay between text and reader with the mediation of tradition and practices. For example, he explains that interpretation should be done by understanding the implications contained in the practice. He also emphasises the importance of the 'historically effected consciousness' - that is, the interpreter who is equipped with the necessary imagination to put himself in the place of those whose past conduct towards one another is being interpreted. ${ }^{67}$

The essentiality of tradition in interpretation is best manifested in Ronald Dworkin's theory, in which legal interpretation is not considered as an activity sui generis, but 'as a mode of knowledge'. ${ }^{68}$ Dworkin considers legal practice to be an interpretive process. Judges disagree on how to decide cases because they disagree about what the law is. In other words, the interpretation of what the law is in any particular case depends upon the judge's conception of law itself. Dworkin makes no distinction between understanding and interpretation, ${ }^{69}$ but distinguishes the interpretation of a conversation from the interpretation of a social practice, the latter of which aims to interpret something created by people as an entity distinct from them. He describes this as 'constructive interpretation', which is a matter of imposing purpose on an object or practice in order to make it the best possible example of the form or genre to which it is taken to belong. ${ }^{70}$ Rejecting the intentionalist theory of meaning, Dworkin uses the image of a chain novel with many authors to ground his concept of interpretation in history, 'not simply to discover what these judges have said, or their state of mind when they said it, but to reach an opinion about what these judges have collectively done'. ${ }^{71}$ This constructive interpretation of the past should 'fit' the practice and show the value of law as a political enterprise. $^{72}$

\footnotetext{
65 ibid 663.

66 ibid 666.

67 ibid 228-229.

68 Ronald Dworkin, 'Law as Interpretation' (1982) 9 Critical Inquiry 179, 182.

69 'We interpret the sounds or marks another person makes in order to decide what he has said' in Ronald Dworkin, Law's Empire (Harvard University Press 1986) 50.

70 ibid 51.

71 Dworkin, 'Law as Interpretation' (n 68) 193.

72 ibid 194.
} 
In his policy oriented approach to law, known as the New Haven School, Myres S McDougal approaches interpretation as a problem in communication, ${ }^{73}$ which should not be limited to the 'arbitrary formalism, 74 of the text of a treaty. He describes language as 'nonsubjective events' which mediate between the subjectivities of the communicator and the audience. ${ }^{75}$ Thus, no act of communication is ever solely 'subjective' or entirely 'nonsubjective', but necessarily involves both simultaneously. ${ }^{76}$ As a result, interpretation not only includes the intentional foundation as the subjective element, but also the usage or conventional theories of meaning that exist in a given social setting. McDougal rejects Vattel's maxim that 'it is not permissible to interpret what has no need of interpretation' as 'an obscurantist tautology, since the determination of the question whether a text required, or did not require, interpretation was itself an interpretation'. ${ }^{77}$ McDougal goes on to argue that there is no such a thing as 'plain and ordinary meaning', because it is only by reference to the factual circumstances of words' use that the meanings of words can be made particular and clear. ${ }^{78}$

For Martti Koskenniemi, the meaning of a rule is not determined 'from the inside' ${ }^{79}$ but derives from the practice of a legal community. ${ }^{80}$ In From Apology to Utopia, he engages with the semiological account of language of Ferdinand de Saussure to describe his concept of international law. Koskenniemi distinguishes between international legal arguments, doctrines and schools as a kind of parole which refers back to an underlying set of assumptions, as langue or 'deep-structure' of the law. ${ }^{81}$ Koskenniemi believes that the underlying assumptions of international law are based on contradictory premises. Therefore, international rules suffer from foundational indeterminacy which goes beyond the indeterminacy of language. ${ }^{82}$ Consequently, the problems of treaty interpretation are deeper than the unclear character of treaty language and 'lie in the contradiction between the legal principles available to arrive at an interpretation' ${ }^{83}$

\footnotetext{
${ }^{73}$ Myres S McDougal and others, The Interpretation of International Agreements and World Public Order: Principles of Content and Procedure (Martinus Nijhoff 1994) 371-372.

74 ibid xvii.

75 ibid 37.

76 ibid 38.

77 ibid 41.

78 ibid 44.

${ }^{79}$ Martti Koskenniemi, From Apology to Utopia: The Structure of International Legal Argument (CUP 2006) 8.

80 'There is no access to legal rules or the legal meaning of international behavior that is independent from the way competent lawyers see those things.' ibid 568.

81 ibid 7-8.

82 ibid 590.

83 ibid 341.
} 
Stanley Fish argues that knowledge is not objective but socially constituted. In other words, understanding is based on the presuppositions of the community in which one lives. Furthermore, the socially conditioned person, ie, everyone, cannot think beyond the limits made possible by his or her culture. As a result, meaning is not found in text but in the reader, or rather the interpretive community: 'the reader's activities are at the center of attention, where they are regarded not as leading to meaning but as having meaning, ${ }^{84}$ As meaning is derived from the community, Fish believes that there is no correct interpretation that will always hold true. Therefore, 'to consult dictionaries, grammars, and histories is to assume that meanings can be specified independently of the activity of reading'. 85

Fish agrees in general with Dworkin's theory that interpretation is neither purely subjective nor objective, however, he blames Dworkin for 'repeatedly fall[ing] away from his own best insight into a version of the fallacies (of pure objectivity and pure subjectivity)...'. ${ }^{86}$ Fish believes that all of the individuals contributing to Dworkin's metaphorical 'chain novel' are as much free as they are constrained, and there is no difference between the first novelists and the others: they are all constrained as they can only create and continue the novel within the constraints of 'novel practice'; but they are free as 'every decision a later novelist makes will rest on his assessment of the situation as it has developed'. ${ }^{87}$ As a result, unlike Dworkin, who believes that the judge 'must interpret what has gone before because he has a responsibility to advance the enterprise in hand rather than strike out in some new direction of his own', ${ }^{88}$ Fish believes that as history does not have 'the status of a brute fact', ${ }^{89}$ it cannot constrain the interpreters. What constrains interpreters is 'their tacit awareness of what is possible and not possible to do, what is and is not a reasonable thing to say, and what will and will not be heard as evidence in a given enterprise...' ${ }^{90}$ They are tacitly aware of the possibilities of interpretation because they are members of interpretive communities, who 'share interpretive strategies not for reading... but for writing texts, for constituting their properties and assigning their intentions'. These interpretive strategies exist 'prior to the act of reading and therefore

\footnotetext{
${ }^{84}$ Stanley E Fish, Is There a Text in This Class? The Authority of Interpretive Communities (Harvard University Press 1980) 158.

85 ibid 152.

${ }^{86}$ Stanley Fish, 'Working on the Chain Gang: Interpretation in the Law and in Literary Criticism' (1982) 9 Critical Inquiry 201, 202.

87 ibid 205.

${ }^{88}$ Dworkin, 'Law as Interpretation' (n 68) 194.

${ }^{89}$ Fish, 'Working on the Chain Gang' (n 86) 208.

90 ibid 211.
} 
[determine] the shape of what is read rather than, as is usually assumed, the other way around'. ${ }^{91}$

In this way, the role of 'interpretive strategies' in Fish's approach is similar to the concept of 'tradition' in Gadamer's theory: it determines the specific 'horizon' of the reader. Fish, however, does not explain how these strategies are shaped. Accordingly, for Fish, the success or failure of interpretation depends on whether '[some]one else would be persuaded to my reading, ${ }^{92}$ while for Gadamer interpretation is successful where the 'fusion of horizons' occurs, that is, when the historically situated author and the equally historically situated reader manage to create a shared meaning.

The evaluation of the validity of considering 'persuasion' as the main criterion for determining a successful act of interpretation, in the face of the criticisms that are raised against Gadamer's concept of the 'fusion of horizons', ${ }^{93}$ is beyond the limited scope of this paper. ${ }^{94}$ The important point for this discussion is, however, that there is general agreement among the many different legal theorists mentioned above about the role of 'tradition' in giving meaning to the text. For example, whereas Raz talks about the 'dependency of language and other carriers of meaning on conventions', Fuller uses the more general term of 'culture'. Likewise, Fish's statement that there are no fixed texts, rather, it is the interpretive strategies that make them fixed, ${ }^{95}$ can be seen as analogous to Hart's claim that plain cases are considered as such because 'there is general agreement in judgments as to the applicability of the classifying terms'. 96

The general agreement among legal theorists on the inadequacy of semantics as an interpretative tool, the dependency of meaning upon social norms and tradition, and thus the relative stability of language, require the law to be understood 'every moment, in every

\footnotetext{
${ }^{91}$ Stanley E Fish, 'Interpreting the "Variorum"' (1976) 2 Critical Inquiry 465, 483

${ }^{92}$ Fish, 'Working on the Chain Gang' (n 86) 281.

${ }^{93}$ Habermas claims that there can be no free engagement in the dialogical situation as long as readers are unknowingly prisoners of ideologies; that they cannot openly interact with texts because of the uncritical acceptance of the institutional bias of vested interests. Gadamer responds that critical reflection cannot lead to any clear view free of prejudice; he argues that because we have our basis in language usage, which is subjective and intersubjective, and there are no universal norms, we cannot overthrow tradition; we must debate within it. Irene Rima Makaryk, Encyclopedia of Contemporary Literary Theory: Approaches, Scholars, Terms (University of Toronto Press 1993) 328. For further discussion on this see: Gayle L Ormiston (ed), The Hermeneutic Tradition: From Ast to Ricoeur (State University of New York Press 1989) 21-23.

${ }^{94}$ For an interesting discussion on the use of 'persuasion' in interpretation of international law see: Andrea Bianchi, 'The Game of Interpretation in International Law' in Andrea Bianchi, Daniel Peat and Matthew Windsor (eds), Interpretation in International Law (OUP 2015) <www.oxfordscholarship.com/view/10.1093/acprof:oso/9780198725749.001.0001/acprof-9780198725749chapter-2> accessed 24 July 2015.

${ }^{95}$ Fish, 'Interpreting the "Variorum"” (n 91) 484.

${ }^{96}$ Hart, The Concept of Law (n 2) 126.
} 
concrete situation, in a new and different way'. ${ }^{97}$ That is why even major legal positivists such as Kelsen and Raz acknowledge the fact that a single legal text can admit of many interpretations. To explain how one object can have several valid interpretations, Raz gives the example of how different interpretations of Hamlet, such as psychoanalytic interpretations, can be valid even though the story has not changed. What has changed is the perspective - the particular reasons for paying attention to that object - which leads to a plurality of valid interpretations. ${ }^{98}$

Of course, asserting the existence of such common elements in the nature of interpretation is by no means equivalent to denying the differences and subtleties of each school of thought discussed above. For example, while Dworkin argues that interpretation is essential to determining what the law is, he also holds that the perfect judge - the metaphorical Judge Hercules, who is invested with a super-human intellect - will always arrive at one right answer. ${ }^{99}$ In contrast, legal hermeneutics views interpretation as the activity of Judge Hermes, who acts within a network 'that can be seen as an infinite volume of instantly available information from which the judge must draw' his conclusion 'in the dialectic play of these possibilities'. ${ }^{100}$ These differences, nonetheless, do not impede us from concluding that, given legal theorists' recognition of the dependency of meaning upon social practices and tradition, legal interpretation, by its nature, is not an exception, and therefore, it is always mediated by the 'tradition' and 'language-games' that exists in a specific community.

\section{NEW READING OF ARTICLES 31 AND 32 OF THE VCLT}

This section applies the framework developed in the above theoretical discussion to the rules of interpretation in international law. In particular, this section asks whether the understanding of the nature of interpretation developed here is consistent with the system provided by the VCLT. Mindful of the controversies which exist concerning the interpretation of international law, the International Law Commission (the 'Commission') opted to codify relatively few rules as 'the strictly legal basis for interpretation'. ${ }^{101}$ These articles are based on the view that the text must be presumed to be the authentic expression of the parties' intentions, and that the

\footnotetext{
${ }^{97}$ Gadamer, Weinsheimer and Marshall (n 11) 308.

${ }^{98} \operatorname{Raz}(\mathrm{n} 51) 263$.

99 Dworkin, 'Law as Interpretation' (n 68) 238-258.

${ }^{100}$ Lenio L Streck, 'Deconstructing the Models of Judges: Legal Hermeneutics and beyond the Subject-Object Paradigm' (2009) 10 Nevada Law Journal 683, 688.

${ }^{101}$ Waldock Third Report (n 5) 54 para 8.
} 
starting point of interpretation is the elucidation of the meaning of the text, not an investigation $\mathrm{ab}$ initio into the intentions of the parties. ${ }^{102}$

VCLT's emphasis on the texts of treaties has led many scholars to advocate for a textual approach to interpretation. The textual school places the principal emphasis on the actual words of a treaty, where the assumption is that the text has a meaning, not merely one given specifically to it by the drafters, but independently. This school finds its support in the 1956 resolution of the Institute of International Law on interpretation ${ }^{103}$ and the formulation of the rules of interpretation proposed by Sir G Fitzmaurice based on the jurisprudence of the International Court of Justice (ICJ), ${ }^{104}$ which assumes the existence of a 'plain' or 'ordinary meaning'.

There is no doubt about the importance of text in the process of interpretation. Interpretation cannot be performed in violation of the facts of a text, but would be an effort to establish those facts. ${ }^{105}$ Gadamer describes this as the ability to open ourselves to the superior claim that a text makes, and to respond to what it has to tell us; to be at its 'service', to subordinate ourselves to the text's claim to dominate our minds, since 'interpretation of law... is clearly not a form of domination but of service'. ${ }^{106}$

Nevertheless, to assume that words have a 'plain' meaning independent from the tradition within which the word is used permits interpreters to interpret legal texts according to whatever seems suitable to them. This is because the meanings of words cannot be derived from their physical properties or reduced to the real-world objects to which they refer. Thus, the danger of the textual approach is that it opens the door to arbitrary interpretations. Because of this ambiguity, the textual approach may create greater uncertainty than an approach which

\footnotetext{
${ }^{102}$ ILC, 'Report of the International Law Commission on the work of its Sixteenth Session' (11 July 1964) UN Doc A/CN.4/173, Commentary to Art 69, 201 para 9.

${ }^{103}$ Article 1 of the resolution provides: 'The agreement of the parties having been reached on the text of the treaty, the natural and ordinary meaning of the terms of that text should be taken as the basis of interpretation. The terms of the provisions of the treaty should be interpreted in the context as a whole, in accordance with good faith and in the light of the principles of international law'. L'Institut de Droit international, 'Interprétation des traités, Rapporteur: MH Lauterpacht'(1956).

104 'I. Principle of actuality (or textuality). Treaties are to be interpreted primarily as they stand, and on the basis of their actual texts. II. Principle of the natural and ordinary meaning... particular words and phrases are to be given their normal, natural, and unstrained meaning in the context in which they occur. in GG Fitzmaurice, 'Law and Procedure of the International Court of Justice: Treaty Interpretation and Certain Other Treaty Points' (1951) 28 British Ybk Intl L 1, 9.

${ }^{105}$ Stanley Fish, Doing What Comes Naturally: Change, Rhetoric, and the Practice of Theory in Literary and Legal Studies (Fredric Jameson ed, Duke University Press Books 1989) 211.

${ }^{106}$ Gadamer, Weinsheimer and Marshall (n 11) 310.
} 
insists upon a comprehensive, contextual examination of all factors potentially relevant to common intent. ${ }^{107}$

Likewise, there was no doubt among the members of the Commission that the text alone is not an adequate source for interpretation, that 'no term had an inherent meaning, the meaning always depended on usage', ${ }^{108}$ and that 'a term in isolation had no meaning'. ${ }^{109}$ This belief was so strong that the term 'natural' for meaning was deleted immediately from the draft articles ${ }^{110}$ as, in the words of Ago, 'the meaning of a term [is] a convention created by the human mind'. ${ }^{111}$ This position was reemphasised by Waldock in his answers to the comments raised by some states about the danger of textualism, saying that "with regard to the expression "ordinary meaning", nothing could have been further from the Commission's intention than to suggest that words had a "dictionary" or "intrinsic meaning in themselves.",112

For precisely these reasons, some members of the Commission doubted the usefulness of adding paragraph 4 of article 31, 'special meaning', to the rules of interpretation, and argued that it could safely be omitted because the so-called 'special' meaning would be the natural meaning in the particular context. ${ }^{113}$ The reason for retaining this paragraph was not because the Commission denied the fact that the technical or special meaning of a term is derived from its context. Rather, the Commission believed that 'there was a certain utility in laying down a specific rule on the point, if only to emphasize that the burden of proof lies on the party invoking the special meaning of the term'. ${ }^{114}$ For this purpose, reference was made to the Legal Status of Eastern Greenland case, in which the Permanent Court of International Justice held: 'The geographical meaning of the word "Greenland", ie the name which is habitually used in the maps to denominate the whole island, must be regarded as the ordinary meaning of the word. If it is alleged by one of the Parties that some unusual or exceptional meaning is to be attributed to it, it lies on that Party to establish its contention'. 115

\footnotetext{
107 'Official Records' United Nations Diplomatic Conference on the Law of Treaties, First session, (UN Conference) (Vienna 26 March-24 May 1968) UN Doc A/CONF.39/11, 31st Meeting, 168 para 48.

${ }^{108}$ ILC, 'Summary record of the 870th meeting' UN Doc A/CN.4/SR.870, Statements of Robert Ago, para 56.

${ }^{109}$ Statements of de Luna, ibid para 57.

${ }^{110}$ The first draft article proposed by Waldock provided under article 70 that ' 1 . The terms of a treaty shall be interpreted in good faith in accordance with the natural and ordinary meaning to be given to each term' [emphasis added]. Waldock Third Report (n 5) 52.

${ }^{111}$ ILC, 'Summary record of the 765th meeting' UN Doc A/CN.4/SR.765, para 80.

112 UN Conference (n 107) 33rd Meeting, Waldock answers, para 70.

113 ibid.

${ }^{114}$ ILC, 'Report of the International Law Commission on the work of its Eighteenth Session' (Final ILC Commentary) (4 May-19 July 1966) UN Doc A/CN.4/191, 222 para 17.

${ }^{115}$ Legal Status of Eastern Greenland case (Denmark v Norway) (Judgment) PCIJ Rep Series A/B No 53, 49.
} 
Another important element of the system of interpretation provided for by the VCLT is the supplementary role that is assigned to the intentions of the authors of a text. Article 32 of the VCLT considers the intentions of the parties as the supplementary element in the process of interpretation. This element is not meant to 'provide for alternative, autonomous, means of interpretation but only for means to aid an interpretation governed by the principles contained in article [31]' ${ }^{116}$ This approach is in line with Gadamer's theory that in conceiving of the past, 'we regain the concepts of a historical past in such a way that they also include our own comprehension of them'. ${ }^{117}$ In other words, we can never access the intention of the parties objectively; rather, it is always mediated by our 'prejudices'.

In the face of the inadequacy of the text alone to serve as the basis of interpretation, on the one hand, and rejecting the intentions of the parties as the foundational bases of meaning, on the other hand, some scholars advocate for the idea that meaning should be ascertained according to the objective that the text is meant to serve. Fitzmaurice describes this teleological approach as another formulation of the rule ut res magis valeat quam pereat, or the principle of maximum effectiveness. ${ }^{118}$ In short, the text should be interpreted to have the fullest value and effect consistent with its wording and with the other parts of the text.

The first draft articles on interpretation proposed by Waldock contained a separate article on effective interpretation ${ }^{119}$ for two reasons: its significance as the basis upon which it is justifiable to imply terms in a treaty for the purpose of giving efficacy to the intention of parties expressed in provisions of the treaty; and that in the sphere of implied terms, it sets the proper limits of the application of the principle, so that purely teleological interpretations are ruled out. ${ }^{120}$ However, this proposal faced strong objections from the members of the Commission, who thought that insofar as this principle stated a logical rule, it was in any case implicit in the requirement of good faith and the reference to the object and purpose of the text. ${ }^{121}$ Ultimately, even Waldock himself was not in favor of retaining the maxim because the 'terms of the treaty itself [would determine] whether the application of the principle led to a

\footnotetext{
${ }^{116}$ Final ILC Commentary (n 114) 223 para 19.

117 Gadamer, Weinsheimer and Marshall (n 11) 367.

${ }^{118}$ Fitzmaurice (n 104) 8.

119 'Article 72. Effective interpretation of the terms (ut res magis valeat quam pereat) In the application of articles 70 and 71 a term of a treaty shall be so interpreted as to give it the fullest weight and effect consistent: $(a)$ with its natural and ordinary meaning and that of the other terms of the treaty; and $(b)$ with the objects and purposes of the treaty'. Waldock Third Report (n 5) 53.

120 ibid 61 para 29.

${ }^{121}$ ILC, 'Summary record of the 766th meeting' UN Doc A/CN.4/SR.766.
} 
restrictive or to an extensive interpretation'. ${ }^{122}$ Therefore, the specific rule on effective interpretation was deleted from the draft articles.

Equating the teleological approach to the principle of effectiveness downgrades the process of interpretation to mere techniques, and thus renders the teleological approach insufficient in explaining the nature of interpretation. Even assuming a larger role for this approach does not make it a proper basis for explaining the nature of interpretation, since this approach either defines the object and purpose as what appears in the text, especially in the preamble, which then makes it a variant of the textual approach; or it seeks to define the object and purpose by going beyond the text and searching for the intentions of the parties, which makes it a variant of the subjective approach. ${ }^{123}$ At best, this approach can only tell us how interpretation should be done.

Nevertheless, it is still believed that the interpretive system provided by the VCLT does not take a strong position with respect to the doctrinal debates on treaty interpretation. ${ }^{124}$ Therefore, the proponents of different interpretative approaches claim that the VCLT provisions privilege the method of their respective approach. The truth however, lies somewhere in the middle. While there is no doubt that text, along with the original intentions and purposes of laws, provides an important insight for the purposes of interpretation, the VCLT rules go beyond these and adopt a unique method based on the dependency of meaning upon tradition and practices.

To illustrate this point, it should be noted that article 31 is formulated as a 'General rule of interpretation' in the singular form, and not as 'General rules'. This formulation emphasises that the provisions of the article form a single, closely integrated rule; that all elements in article 31 would be thrown into the crucible, and their interaction would give the legally relevant interpretation. 125

The rule that the ordinary meaning of a term is not to be determined in the abstract, but in the context of the treaty and in the light of its objects and purposes is, according to the Commission, necessary according to both common sense and good faith. ${ }^{126}$ The inclusion of the preamble and annexes in the 'context' is well settled. Any agreement relating to a treaty,

\footnotetext{
122 ibid para 70.

${ }^{123}$ Francis G Jacobs, 'Varieties of Approach to Treaty Interpretation: With Special Reference to the Draft Convention on the Law of Treaties Before the Vienna Diplomatic Conference' (1969) 18 International \& Comparative Law Quarterly 318, 319.

${ }^{124}$ ILC, 'Report of the Study Group of the International Law Commission, Fragmentation of International Law: Difficulties Arising Form the Diversification and Expansion of International law, Finalized by Martti Koskenniemi' (ILC Study on Fragmentation) (13 April 2006) UN Doc A/CN.4/L.682, para 427.

${ }^{125}$ Final ILC Commentary (n 114) 219 para 8.

126 ibid 221 para 12.
} 
and any instrument which was made in connection with the conclusion of that treaty, 'should not be treated as mere evidence to which recourse may be had for the purpose of resolving an ambiguity or obscurity, but as part of the context for the purpose of arriving at the ordinary meaning of the terms of the treaty'. ${ }^{127}$ The Commission also introduced three extrinsic elements 'to be taken into account together with the context': agreement as to the interpretation of a provision reached after the conclusion of the treaty; any subsequent practice in the application; and any relevant rules of international law.

The Commission emphasised that the 'context' was not meant to refer only to the text of the treaty but was designed to 'link all the elements of interpretation mentioned in paragraph 2 to the word 'context' in the first paragraph and thereby incorporate them in the provision contained in that paragraph. Equally, the opening phrase of paragraph 3 clarifies that the statement "There shall be taken into account together with the context" [was] designed to incorporate in paragraph 1 the elements of interpretation set out in paragraph $3{ }^{\prime}{ }^{128}$

Listing the primary sources for interpreting treaties as articulated in article 31 , in the words of El-Erian, does not justify the establishment of a hierarchical order. Rather, it merely reflects the logical presentation of these sources. ${ }^{129}$ This view is also reflected in the Commentary of the Commission on the rules of interpretation, highlighting the fact that the only reason for formulating article 31 in such a way is that these sources 'have, in the nature of things, to be arranged in some order'. ${ }^{130}$ In response to the comments raised during the Diplomatic Conference of 1969, Waldock explains that the intention of the Commission had been to place on the same footing all of the elements of interpretation mentioned in article 31. ${ }^{131}$ Therefore, 'it is only logic which suggests that the elements in paragraph 3 (the subsequent agreement regarding the interpretation, subsequent practice establishing the understanding of the parties regarding the interpretation, and relevant rules of international law applicable in the relations between the parties) should follow and not precede the elements in the previous paragraphs'. And due to the 'obligatory character' of these elements, they cannot be considered 'to be norms of interpretation in any way inferior to those, which precede them'. ${ }^{132}$

\footnotetext{
127 ibid para 13.

128 ibid 219 para 8.

${ }^{129}$ ILC, 'Summary record of the 871st meeting' (ILC 871st Meeting) UN Doc A/CN.4/SR. 871 para 27.

${ }^{130}$ Final ILC Commentary (n 114) 220 para 9.

${ }^{131}$ UN Conference (n 107) 33rd Meeting, Waldock answers, para 72.

${ }^{132}$ Final ILC Commentary (n 114) 220 para 9.
} 
The technical discussion that exists among scholars about the requirements of each element listed in article 31 is beyond the scope of this paper. What is important for our discussion is that the elements listed in article 31 are either related to what is set by the parties, or to what the 'tradition' and 'practice' requires. These two categories of elements correspond to the two types of social norm theories of meaning: the conventionalist theory, which regards 'unambiguous linguistic usage, reached by agreement' as the source of meaning; and, what Gadamer calls 'customary usage' theory, which sets limits to conventionalism in order to avoid arbitrariness in interpreting the meanings of words. To illustrate his theory, Gadamer gives the examples of children and lovers who have 'their' language 'by which they communicate with each other in a world that belongs to them alone. But even this is not so much because they have arbitrarily agreed on it, but because a verbal custom has grown up between them'. ${ }^{133}$

The nature of international law requires taking into account the 'conventionalist theory' to determine meaning based on the acts of the law's subjects. At the same time, the nature of interpretation and understanding require us to understand legal terms through the mediation of the language-games that are present in a given tradition. This is achieved by the inclusion of 'the relevant rules of international law' as the primary source for the interpretation of treaties. The determination of meaning by considering the 'relevant rules of intentional law' requires the consideration of not only the formal sources of international law, but also, as article 38(1)(d) of the ICJ Statute provides, of the judicial practices and doctrine for determination of rules of law. ${ }^{134}$ This means that in every interpretation of the terms of treaties, the text should be understood not only by reference to 'what is agreed' by the parties, but also in the light of the

\footnotetext{
133 Gadamer, Weinsheimer and Marshall (n 11) 406- 407.

134 There are several examples in the judicial practice to reaffirm this position, for example in Djibouti v France, the ICJ held that the provisions of the 1977 Treaty of Friendship and Cooperation are 'relevant rules' within the meaning of Article 31(3)(c) of VCLT for the interpretation of the Convention on Mutual Assistance in Criminal Matters of 1986. Certain Questions of Mutual Assistance in Criminal Matters (Djibouti v France) (Judgment) ICJ Rep 2008, 177, paras 112-114; in Esphahanian v Bank Tejarat, the Iran-US Claim Tribunal, by virtue of article $31(3)$ (c) of the VCLT, applied the customary rules on the law of diplomatic protection to determine whether a claimant who had dual Iran/US nationality might bring a claim before the Tribunal. Esphahanian v Bank Tejarat (1983) I Iran-USCTR 157; in Golder v United Kingdom, the Court by deploying article 31(3)(c) for interpretation of article 6 of ECtHR referred in turn to article 38(1)(c) of the Statute of the ICJ and found that the right of access to civil courts is a general principle of law, and could be relied upon in interpreting that article. Golder $v$ the United Kingdom (Judgment) ECHR Series A (1975) No 18, paras 27-31; in Bankovic v Belgium and others, ECtHR for interpreting the words 'within their jurisdiction', in accordance with article 31(3)(c) of VCLT, made a recourse, inter alia, to judicial practice and legal doctrines. Bankovic v Belgium and others (Decision of 12 December 2001. Admissibility) ECHR 2001-XII 351, paras 57-65; and in Azurix v Argentina: the ICSID Tribunal held that it 'is required to consider the ordinary meaning of the terms used in the BIT under article 31 of [VCLT]', and thus, 'the findings of other tribunals, and in particular of the ICJ, should be helpful to the Tribunal in its interpretive task'. Azurix Corp v The Argentine Republic (Award) ICSID Case No. ARB/01/12 (14 July 2006) para 391.
} 
relevant legal tradition. ${ }^{135}$ The essentiality of determining the meaning of terms in the virtue of the 'relevant rules of international law', or in other words, the 'language-games' that exist in international law, is best reflected in the following passage from one of the members of the Commission:

The reference to the rules of international law was indispensable, for just as a term could only be understood in a sentence, a sentence only in an article, and an article only in the treaty as a whole, it was impossible to understand the treaty except within the whole international legal order of which it formed a part, which it influenced and by which it was influenced. A treaty was an act of will; the parties had reached agreement, but their agreement was not in vacuo; it was situated in a legal order. In using certain terms, the parties had in mind concepts and meanings established by the legal order. ${ }^{136}$

The determination of meaning with reference to the 'language-games' of a particular community requires 'other rules' to be applied to a case which do not derive from the treaty under interpretation. It might be suggested that international tribunals are not entitled to apply the law that goes 'beyond' the four corners of the instrument that establishes the jurisdiction of the tribunal. This belief is caused by confusion in the concepts of 'jurisdiction' and the 'applicable law'. Although the jurisdiction of most international tribunals is limited to particular types of disputes, or disputes arising under particular treaties, this limited jurisdiction does not necessarily imply a limitation of the scope of the law applicable in the interpretation and application of those treaties. ${ }^{137}$ For example, the United Nations Convention on the Law of the Sea provides that the Tribunal has 'jurisdiction over any dispute concerning the interpretation and application of this Convention', however, when deciding cases, it 'shall apply this Convention and other rules of international law not incompatible with this Convention'. ${ }^{138}$ Similarly, although without any express provision in the Statutes, the limited

\footnotetext{
${ }^{135}$ In the Dialo case, the ICJ held that for interpreting the relevant previsions of ICCPR and African Charter of Human and People's Rights, 'it should ascribe great weight to the interpretation adopted by ... independent body that was established specifically to supervise the application of that treaty'. As a result, the Court referred not only to the practice of the Human Right Committee and the African Commission on Human and Peoples' Rights, but also to the practices of the ECtHR and IACHR. Ahmadou Sadio Diallo (Republic of Guinea v Democratic Republic of the Congo) (Judgment) 2010 ICJ Rep 639, paras 66-68.

${ }^{136}$ Statements of Yasseen, ILC 871st Meeting (n 129) para 51.

${ }^{137}$ ILC Study on Fragmentation (n 124) para 45.

${ }^{138}$ Articles 288(1) and 293(1) of the UNCLOS. As an example, in Mauritius v UK, the Tribunal in addressing the challenge raised by Mauritius against Judge Greenwood, held that the law applicable to such arbitration is that to be found in Annex VII of the Convention 'supplemented by the law and practice of international courts and tribunals in inter-State cases'. On the other hand, the Tribunal declared that the law developed by non-international organisations, such as IBA guidelines, or the practice of non inter-state tribunals cannot be considered as relevant. Chagos Marine Protected Area Arbitration (Mauritius v UK) (Reasoned Decision on Challenge, 30 November 2011) PCA
} 
jurisdiction of the ad hoc international criminal tribunals has not impeded the application of the sources, in particular customary law, ${ }^{139}$ enshrined in article $38(1)$ of the Statute of the ICJ. ${ }^{140}$

The distinction between jurisdiction and 'other rules' of international law which will be applied as a matter of interpretation is well reflected in the Pulp Mill on the River Uruguay judgment, in which the Court states that in the interpretation of the 1975 Statute, taking account of relevant rules of international law applicable in the relations between the Parties, whether these are rules of general international law or contained in multilateral conventions to which the two states are parties, nevertheless has no bearing on the scope of the jurisdiction conferred on the Court ... which remains confined to disputes concerning the interpretation or application of the Statute'. ${ }^{141}$ This is because 'interpretation does not "add" anything to the instrument that is being interpreted. It constructs the meaning of the instrument by a legal technique ... that involves taking account of its normative environment'. ${ }^{142}$ That is why in the Oil Platforms case, the international law on the use of force was applied to determine the meaning of 'necessity' in Article XXI, paragraph 2 of the 1955 Treaty of Amity between Iran and the United States. The ICJ held that 'the interpretation and application of that Article will necessarily entail an assessment of the conditions of legitimate self-defense under international law', because 'application of the relevant rules of international law relating to this question ... forms an integral part of the task of interpretation'. ${ }^{143}$ Similarly, the Permanent Court of

\footnotetext{
<www.pca-cpa.org/Reasoned\%20Decision\%20on\%20Challenge1fcb.PDF?fil_id=1782> accessed 21 July 2015, para 165.

139 The prominent place of customary law in the practice of ICTY and ICTR has allowed one of the most significant innovations in the modes of criminal liability: the joint criminal enterprise. For further discussion on this see, for instance: Philippa Webb, International Judicial Integration and Fragmentation (OUP 2013) 176.

${ }^{140}$ See, for example, Prosecutor v 'Pavo', Hazim Delic, Esad Landzo (Judgment) IT-96-21-T (16 November 1998) para 414; and Prosecutor v Zoran Kupreskic, Mirjan Kupreskic, Vlatko Kupreskic, Drago Josipovic, Dragan Papic, Vladimir Santic (Judgment) IT-95-16-T (14 January 2000) para 540.

${ }^{141}$ Pulp Mills on the River Uruguay (Argentina v Uruguay) (Judgment) 2010 ICJ Rep 14, para 66.

142 ILC Study on Fragmentation (n 124) para 447.

${ }^{143}$ Oil Platforms (Islamic Republic of Iran v United States of America) (Judgment) 2003 ICJ Rep 161, paras 4041. While this case remains a controversial one, the operative paragraph (1), which, inter alia, evaluates the action of the US under the law of the use of force, was adopted by fourteen votes against two. Whereas the two dissenting judges had no objections to the application of international law on the use of force for interpretation of article XXI (see Dissenting Opinion of Judge Al-Khasawneh 109, and Dissenting Opinion of Judge Elaraby 133), a few judges, in their separate opinions, disagreed with the approach of the Court: Judge Odawa and Judge Kooijmans did not reject the interpretation of the article by reference to other rules, however they believed that, due to the limited jurisdiction of the Court, only the necessary elements of international law on the use of force should have been considered (Separate Opinion of Judge Odawa paras 35-40; Separate Opinion of Judge Koojimans para 52); Judge Higgins argued that the Court should have interpreted the particular provisions in light of general international law, as to their 'specific terms' and not to essentially replace them with the law on armed attack and self-defense (Separate Opinion of Judge Higgins paras 48-50); and Judge Buergenthal believed that the interpretation of that article in light of the international law on the use of force exceeded the Court's jurisdiction (Separate Opinion of Judge Buergenthal paras 20-32). On the other side, it suffices to quote Judge Koroma, who stated that 'the Court applied this rule, as it was bound to do, and came to the conclusion that the Article was not
} 
Arbitration in Iron Rhine arbitration held that: 'it is to be recalled that Article 31, paragraph 3, subparagraph (c) of the Vienna Convention on the Law of Treaties makes reference to "any relevant rules of international law applicable in the relations between the parties". For this reason ... the Tribunal has examined any provisions of European law that might be considered of possible relevance in this case ... Provisions of general international law are also applicable to the relations between the Parties, and thus should be taken into account in interpreting Article XII of the 1839 Treaty of Separation and Article IV of the Iron Rhine Treaty. Further, international environmental law has relevance to the relations between the Parties' ${ }^{144}$

To adhere to the idea that a tribunal may not be entitled to apply the relevant rules of international law in treaty interpretation is to hold that 'once [s] tates conclude a bilateral treaty, they create a vacuum that consists precisely of this type of exclusion'. ${ }^{145}$ To avoid such a result, the World Trade Organization (WTO) Appellate Body has rejected the idea that the covered treaties form a closed system, and has held that WTO agreements should not be read 'in clinical isolation from public international law'. ${ }^{146}$ Thus, the Appellate Body in the Shrimp-Turtle case, held that the concept of 'exhaustible natural resources' in article XX(g) of GATT should be interpreted within current 'tradition' in international law and, as a result, it referred, among other instruments, to the 1992 Rio Declaration and Agenda 21, the Biodiversity Convention of 1992, and the United Nations Convention on the Law of the Sea. The Appellate Body thereby reached the conclusion that all natural resources, living and non-living, were included in the concept 'exhaustible natural resources'. ${ }^{147}$ This example, as well as the ones discussed above, show clearly that the theoretical approach provided in this paper is not a radical departure from what is already being done. On the contrary, it maps onto current practice and provides a sound foundation to understand why tradition is so important to interpretation in the context of international law.

\section{E. CONCLUDING REMARKS}

This paper provides a theoretical approach to the nature of interpretation in international law by adhering to the approaches of Gadamer and Wittgenstein. Such philosophical-linguistic

\footnotetext{
intended to operate wholly independently of general international law on the use of force, so as to be capable of justifying, even in the limited context of a claim for breach of the Treaty, the unlawful use of force' (Declaration of Judge Koroma 66).

${ }^{144}$ Iron Rhine Railway (Belgium v Netherlands) (Decision of 24 May 2005) RIAA Vol XXVII. 35-125, para 58.

${ }^{145}$ ILC Study on Fragmentation (n 124) para 460.

${ }^{146}$ United States - Standards for Reformulated and Conventional Gasoline (29 April 1996) WT/DS2/AB/R, 17.

147 United States - Import Prohibition of Certain Shrimp and Shrimp Products (6 November 1998) WT/DS58/AB/R, DSR 1998:VII, 2794-2797, paras 127-131.
} 
approaches suggest that we do not discover meaning by limiting our vision to bare text, or to the original intentions of authors. Rather, the 'tradition' and 'language-games' within a specific community determine the meanings of terms used in that community. While the applicability of such an insight to law, which is aimed at providing its subject with certainty and stability, might be questioned, reviewing the approaches of different legal theorists reveals that, despite their differences, the dependency of meaning upon social practices and tradition is acknowledged by all of them. Therefore, it is concluded that legal interpretation, by its nature, is no exception and is always mediated by the 'tradition' and 'language-games' of specific communities.

This finding paves the way for a new reading of the system of interpretation provided by articles 31 and 32 of VCLT. It is argued that although the VCLT integrates some of the elements of current interpretive methods, ultimately it adopts its own unique approach based on the dependency of meaning upon 'tradition'. Whereas the nature of international law requires one to take into account the 'conventionalist theory' and to determine meaning based on the acts of the law's subjects, the nature of interpretation requires that the terms be understood with the mediation of the 'language-games' existing in that community. This is recognised in the VCLT system of interpretation by the inclusion of 'the relevant rules of international law' as the primary source for the interpretation of treaties. Therefore, according to the VCLT rules, in every interpretation of the terms of treaties, the text should be understood not only by reference to what the law's subjects have agreed or will agree on, but also, and more importantly, in light of the relevant legal 'tradition'. 